\title{
DISONANSI MAKNA CANTIK REMAJA DI KOTA WAINGAPU
}

\author{
Rambu Naha ${ }^{1}$ \\ ${ }^{1}$ Program Studi Pendidikan Jarak \\ Jauh Ilmu Komunikasi, Universitas \\ Pelita Harapan \\ $\mathrm{MH}$ Thamrin Boulevard, Lippo \\ Village, Tangerang, DKI Jakarta \\ 15810
}

\section{Correspondence \\ Rambu Naha \\ Program Studi Pendidikan Jarak Jauh Ilmu Komunikasi, \\ Universitas Pelita Harapan \\ Email: rambu.naha@uph.edu}

https://doi.org/10.26905/nomosleca. v7i1.5485

\begin{abstract}
Beauty is defined through the process of social interaction and the use of symbols. Social interaction could define distinct meaning about reality. Youths in Waingapu, East Timor, interact within cultural context that is filled with values passed from generation to generation, and that includes how to define the meaning of beauty. As youths who live in an era of fast development of conventional and social media, youths are interacting with both cultural and social - constructed by media values. This research aims to describe how the meaning of beauty is defined in Waingapu. To accomplish its objective, the research uses descriptive qualitative approach by conducting interview with ten youths from Waingapu. The result shows that youths in Waingapu define meaning of beauty from two opposite sides. They are facing a dissonance in which two values are going to two different directions. They however realize that the meaning of beauty is mainly defined by character - in accordance with the culture of people in Sumba - but they are unable to set aside the ideas that are constructed by media on the definition of beauty.
\end{abstract}

Keywords: Meaning of beauty, Symbolic interactionism, Youths

\begin{abstract}
Abstrak: Interaksi dalam konteks sosial melahirkan pemaknaan berbeda atas realitas. Remaja di kota Waingapu, Nusa Tenggara Timur, berinteraksi dalam konteks budaya dengan nilai cantic yang terus diwariskan setiap generasi. Remaja hidup dalam perkembangan media digital, sehingga berinteraksi dengan nilai budaya dan nilai kecantikan konstruksi media. Penelitian menggambarkan makna kecantikan bagi remaja. Peneliti menggunakan pendekatan kualitatif deskriptif, melalui wawancara mendalam sepuluh orang remaja di kota Waingapu. Hasil penelitian pemaknaan kecantikan dari dua sisi yang bertolak belakang. Remaja mengalami disonansi makna, yakni kondisi terdapat dua nilai kecantikan yang saling berlawanan. Remaja menyadari nilai utama kecantikan terletak pada karakter, sesuai dengan nilai masyarakat Sumba. Tetapi juga melakukan penilaian berdasarkan konstruksi media.
\end{abstract}

Kata Kunci: Makna Cantik, Interaksi Simbolik, Remaja 


\section{1 | PENDAHULUAN}

Dalam proses interaksi sosial, manusia berbagi pengertian mengenai istilah atau tindakan tertentu untuk memahami sebuah realitas (Littlejohn \& Foss, 2009). Interaksi sosial berawal dari interaksi antar individu yang kemudian menghasilkan makna (Dennis, 2011). Blumer (1969) sebagai mana dikutip dari Carter \& Fuller (2015) mengatakan bahwa bahwa makna merupakan sesuatu yang dirasakan dan bersifat intersubjective, serta terus menerus ditafsirkan ulang diantara individuindividu yang berinteraksi. Makna lahir dari pengalaman manusia (Fridha \& Octavianti, 2016) dan dapat dilihat dari cara penerima pesan memberikan respon atas stimulus yang diterimanya dari komunikator (Smith, 1980). Makna terkait dengan fenomena atau aktivitas dalam sebuah kelompok masyarakat yang dapat terus menerus dibagikan dan kemudian dapat membentuk cara pandang yang sama diantara anggota kelompok.

Makna merupakan hal yang mendasar dalam konsep interaksi simbolik (Aksan et al., 2009). Terminologi interaksi simbolik pertama kali diperkenalkan oleh Herbert Blumer pada 1969, yang didasarkan pada catatan kuliah dari profesornya yang bernama George Herbert Mead. Catatan kuliah tersebut kemudian dipublikasi dalam sebuah buku yang diberi judul Mind, Self, and Society (Griffin et al., 2015). Konsep mengenai mind berbicara mengenai isyarat dan simbol yang kemudian diinterpretasikan dan direspon menjadi sebuah proses interaksi yang melahirkan makna (Mead, 1934). Self merupakan proses reflektif dari seorang individu berdasarkan pada pengalaman sosialnya (Callero, 2003). Society sendiri merupakan sebuah asosiasi dimana setiap individu dapat membangun proses pertukaran simbol yang melahirkan makna (Blumer, 1969). Interaksi simbolik berfokus pada bagaimana masyarakat dibentuk dan dipertahankan melalui interaksi yang terus berulang diantara individu (Carter \& Fuller, 2015). Kajian dari Blumer 1966 (Snow, 2001) menyebutkan tiga prinsip utama dalam interaksi simbolik yaitu 1) tindakan seseorang dalam interaksi dengan orang lain didasarkan pada makna yang ada diantara mereka, 2) makna berasal dari interaksi sosial dengan orang lain, dan 3) makna kemudian ditransformasikan melalui proses interpretasi dari pihakpihak yang terlibat untuk memahami objek yang ada dalam kehidupan sosial mereka.

Makna cantik bagi remaja perempuan juga merupakan sebuah produk dari interaksi sosialnya. Perempuan umumnya memiliki penilaian akan standar kecantikan diri yang lebih negatif dari pada laki-laki, sebagai hasil dari membandingkan diri dengan orang lain, berdasarkan nilai budaya masyarakat dan juga dengan dengan teman sebaya (Strahan et al., 2006). Upaya membandingkan 
diri ini sesungguhnya merupakan mekanisme dasar psikologis seseorang karena adanya pertimbangan motivasional (Corcoran et al., 2011). Salah satu motivasi yang mendorong seseorang membandingkan diri dengan orang lain adalah untuk melakukan evaluasi (Miller et al., 2015). Evaluasi diperoleh dari adanya interaksi yang memungkinkan seseorang mengalami proses belajar (Nabavi, 2012). Proses belajar terhadap fenomena dapat dihasilkan dari pengalaman langsung dan juga dari sebuah keterwakilan berdasarkan perilaku orang lain dan konsekuensinya (Bandura, 1971), serta dari informasi simbolik seperti bahasa (Weisner \& Silver, 1981).

Media dapat menjadi sarana atau alat bagi remaja untuk belajar memahami dan memaknai realitasnya, termasuk memaknai kecantikan. Kehadiran media turut membentuk bagaimana remaja memandang konsep kecantikan yang ideal secara negatif (Bertilsson \& Gillberg, 2017). Saat ini media sosial juga menjadi bagian yang tidak terpisahkan bagi kaum muda (Laarhoven \& Wang, 2018), khususnya untuk berinteraksi (Kasturi \& Vardhan, 2014), berbagi informasi dan konektivitas (Obar \& Wildman, 2015). Kehadiran media merubah pola kehidupan remaja, dimana media digunakan untuk memperoleh sudut pandang dari masyarakat (Paus-Hasebrink et al., 2019). Dapat dikatakan bahwa media dapat menjadi rujukan bagi seseorang untuk dapat mengevaluasi diri, khususnya bagi kaum muda yang selalu fokus pada membangun presentasi diri (Livingstone, 2008). Media menjadi alat yang mampu membangun konstruksi mengenai bagaimana seharusnya gambaran tubuh perempuan (Nagar \& Virk, 2017).Gambaran tubuh perempuan secara signifikan menjadi lebih negatif setelah menyaksikan bagaimana media menggambarkan tubuh ideal yang kurus (Mills et al., 2017). Gambaran yang ada di media semakin menarik waktu dan perhatian dari remaja (Webb et al., 2017). Media memiliki peranan yang besar sebagai sarana interaksi dan belajar mengenai nilai-nilai yang ada di masyarakat termasuk nilai mengenai kecantikan

Sebuah studi yang dilakukan di Accra, Ibu Kota Ghana, menunjukan bahwa media menjadi rujukan dalam menentukan standar penampilan termasuk fashion bagi wanita muda yang telah bekerja (Adjin-Tettey, 2015). Sebanyak 88,4\% responden $(n=100)$ menyetujui bahwa gambaran atau standar kecantikan yang ada di media merupakan hal yang realistis untuk dicapai. Selain media, wanita muda di Accra juga mengevaluasi gambar diri dan kecantikan mereka melalui upaya membandingkan diri dengan kelompok sebaya (43,9\%), meskipun proses membandingkan diri melalui media tetap memiliki presentasi yang lebih tinggi (64\%).

Beragam iklan produk kecantikan yang dipromosikan di berbagai media dapat menjadi alat untuk membentuk cara perempuan memaknai kecantikan. Penelitian yang dilakukan oleh Prijanti (2013) menunjukan bahwa iklan produk kecantikan, memberikan sudut pandang bagi perempuan di Indonesia mengenai bagaimana 
kecantikan dimaknai berdasarkan standar fisik berupa kulit putih, bentuk tubuh yang ideal, dan penampilan yang terlihat muda. Salah satu temuan yang juga menarik dalam penelitian ini adalah konsep kencantikan yang dibagikan media justru belum tentu sesuai dengan moral dan etika budaya masyarakat, walaupun penelitian ini belum mampu menggambarkan nilai kecantikan perempuan pada beragam suku dan budaya yang ada di Indonesia.

Walaupun media dapat menjadi alat untuk mengonstruksi pemaknaan perempuan mengenai kecantikan, tetapi perempuan memiliki kekuasaan untuk mengabaikan atau menolak konstruksi tersebut. Septiani (2013) melakukan penelitian untuk melihat pemahaman perempuan pada terpaan konstruksi kecantikan pada sebuah akun kecantikan di Instagram. Informan dalam penelitian ini adalah kalangan mahasiswi atau dapat dikatakan sebagai kalangan terpelajar. Penelitian ini justru menemukan bahwa tidak semua perempuan memaknai kecantikan berdasarkan hegemoni makna kecantikan yang sering ditampilkan di media.

Berdasarkan penelitian-penelitian terdahulu dapat dilihat bahwa media menjadi saluran dalam membangun konstruksi terhadap makna kecantikan khususnya bagi perempuan. Meskipun demikian, media bukanlah faktor tunggal yang dapat membangun makna mengenai realitas. Individu yang terlibat dalam interaksi sosial memiliki kendali untuk menerima atau menolak konstruksi nilai media. Dalam proses interaksi, individu tidak saja belajar dari nilai yang ada di media tetapi juga dengan konteks sosial termasuk budaya yang ada di lingkungan sosialnya.

Kecantikan perempuan dapat dimaknai secara berbeda sesuai dengan konteks sosial, budaya, dan jaman. Cantik seringkali dimaknai sebagai kombinasi antara inner beauty (faktor psikologis seperti karakter pribadi, kepintaran, kesopanan) dan outer beauty yang berupa penampilan fisik (Ben-Nun, 2016). Bangsa Mesir Kuno memaknai kecantikan yang dilihat dari karakter dan penampilan fisik (ramping dan terlihat muda), dan sebagai ciptaan Tuhan manusia harus selalu tampak sempurna (El-Kilany \& Raoof, 2017). Dalam budaya Afrika, konsep kecantikan tidak saja diartikan sebagai kecantikan fisik dan psikologis atau bersifat individualistik, tetapi kecantikan memiliki tujuan untuk memenuhi nilai secara komunal demi tercapainya harmoni (Ibanga, 2017). Masyarakat Sumba dalam budaya patriarki, menekankan nilai kecantikan seorang perempuan pada terpenuhinya karakter-karakter feminin untuk menjalankan perannya kelak sebagai seorang istri dan ibu.

Dalam konteks budaya, masyarakat Sumba masih sangat memegang kuat nilai budaya yang diwariskan secara turun temurun, termasuk juga mengenai harapan akan sifat dan karakter perempuan Sumba. Ditengah kuatnya konstruksi nilai budaya yang ada di Sumba, perkembangan teknologi informasi dan komunikasi 
hadir dan menjadi bagian yang tidak terpisahkan bagi kehidupan masyarakat di Sumba, secara khusus di kota Waingapu. Letaknya yang strategis dengan akses penerbangan dan pelabuhan laut, menjadikan kota Waingapu paling berkembang dibandingkan dengan kota lain di Pulau Sumba. Meskipun secara geografis Waingapu terletak jauh dari Pulau Jawa yang memiliki banyak kota besar dan modern termasuk Jakarta, namun jaringan televisi nasional, televisi kabel dan juga internet merupakan hal yang umum digunakan masyarakat yang tinggal di pusat kota Waingapu. Akses terhadap media dan teknologi ini memungkinkan masyarakat di kota Waingapu untuk selalu terekspos dengan konstruksi kecantikan yang ada di media.

Remaja merupakan kelompok usia yang paling dekat dengan perkembangan media dan teknologi. Remaja di kota Waingapu dapat dikategorikan dalam generasi Z yang lahir tahun 1995-2010 (Andrea et al., 2016). Genererasi Z hidup berdampingan dengan perkembangan media dan teknologi komunikasi, yang memungkinkan mereka saling terhubung, dan dekat dengan pemanfaatan sosial media (Gaidhani et al., 2019). Kajian dari Arczyńska-Dobiesz \& Chomątowska 2014 (dikutip dalam Dolot, 2018), menyebutkan bahwa generasi ini dapat beradaptasi baik di dunia real maupun virtual, sebagai dunia yang saling melengkapi. Media dengan konstruksi nilai kecantikan sebagaimana yang ada di penelitian terdahulu, turut menyatu dalam interaksi sosial remaja di Waingapu.

Remaja di kota Waingapu berinteraksi dengan nilai budaya dan juga nilai yang diperoleh melalui media. Secara budaya perempuan di Sumba termasuk di Waingapu dituntut untuk dapat mewujudkan kecantikan karakter atau inner beauty, sedangkan di media nilai cantik seorang perempuan banyak dikonstruksikan dalam standar dan ciri fisik tertentu. Apabila dikaji dalam konsep interaksi simbolik dimana makna merupakan hasil dari proses interaksi, maka interaksi remaja di Waingapu menyatu dengan dua konstruksi makna yang berbeda, yakni interaksi dengan lingkungan sosial budaya dan juga media. Kondisi ini mendorong peneliti untuk melihat makna kecantikan sebagai hasil dari proses interaksi remaja di kota Waingapu.

\section{2 | METODE PENELITIAN}

Penelitian ini menggunakan pendekatan kualitatif dengan metode deskriptif yang berusaha untuk memberikan gambaran spesifik mengenai situasi, social setting atau hubungan (Neuman, 2014), dan dalam hal ini mengenai makna kecantikan khususnya bagi remaja yang ada di Kota Waingapu. Makna dalam penelitian ini dilihat dari perspektif interaksi simbolik, dimana makna lahir dari proses interaksi yang kemudian diinterpretasikan oleh pihak-pihak yang terlibat (Blumer, 1969). Oleh karena itu, makna kecantikan bagi remaja di Waingapu dilihat sebagai 
hasil dari proses interaksi yang terjadi dalam konteks sosial masyarakat. Data dalam penelitian ini diperoleh melalui wawancara mendalam pada 10 remaja wanita di Kota Waingapu berusia 16-19 tahun. Informan sebagai subjek penelitian dipilih mewakili generasi $Z$ yang merupakan generasi digital atau yang sering disebut dengan digital natives yang lahir tahun 1995-2010 (Andrea et al., 2016). Informan juga merupakan remaja yang tinggal di pusat Kota Waingapu sehingga akses terhadap teknologi dan media, baik media konvensional maupun media sosial, merupakan hal yang telah menjadi bagian dari kehidupan sehari-hari. Penelitian ini dilakukan selama bulan Januari 2021, dan bertujuan untuk melihat pemaknaan mengenai kecantikan bagi remaja yang ada di Kota Waingapu.

\section{3 | HASIL DAN PEMBAHASAN}

Masyarakat Sumba khususnya Waingapu merupakan sebuah society atau asosiasi dalam konsep Blumer, yang dibangun dari adanya proses komunikasi dan interaksi yang melahirkan makna dan kemudian membentuk pehaman akan realitas. Kristalisasi dari proses interaksi yang intersubjektif ini membentuk budaya, falsafah, atau cara pandang dalam memahami realitas sebagai sebuah kelompok masyarakat. Nilai-nilai budaya leluhur masih terus dipegang dengan kuat oleh masyarakat Sumba, meskipun sering kali tidak dapat diterima dalam pandangan masyarakat modern. Contohnya dapat terlihat pada upacara kematian yang membutuhkan waktu bertahun-tahun untuk menguburkan jenazah orang Sumba, ditambah dengan banyaknya hewan yang harus dikorbankan dalam upacara tersebut, baik untuk menjamu setiap suku (klan) yang hadir, ataupun yang digunakan sebagai bagian dari ritual. Dalam adat pernikahan pun, orang Sumba masih menjalankan tradisi belis (mahar) yang sangat tinggi untuk dapat meminang seorang perempuan Sumba. Umumnya belis ini dihargai dengan memberikan hewan berupa kuda dan kerbau dalam jumlah yang banyak, yang tentunya membutuhkan biaya yang sangat tinggi. Dalam perspektif masyarakat modern yang memiliki pertimbangan hidup yang praktis dan efisien secara ekonomi, praktikpraktik budaya yang membutuhkan biaya yang besar ini tentu menjadi tidak populer.

Dalam konteks budaya, masyarakat Sumba merupakan masyarakat patriarki, dimana posisi pria lebih dominan dibandingkan dengan perempuan dalam struktur sosial (Soman, 2009). Meskipun demikian, perempuan Sumba diberikan penghargaan yang tinggi dalam sistem budaya. Hal ini terlihat dari adanya belis yang diberikan pada saat seorang perempuan Sumba dipinang. Mahar bagi seorang perempuan Sumba dibuktikan dengan memberikan harta benda yang menjadi simbol kekayaan bagi masyarakat Sumba. Kekayaan masyarakat Sumba terlihat 
dari banyaknya ternak, kain tenunan, dan perhiasan yang dimiliki.

Perempuan Sumba dipersiapkan untuk dapat menjadi seorang istri, ibu, dan menantu yang dihargai ketika nantinya ia harus berumah tangga. Untuk itu, perempuan Sumba dituntut memiliki karakter feminin seperti dapat bekerja di dapur, mengurus rumah, melahirkan keturunan, serta ketulusan untuk melayani dan merawat orang tua serta keluarga suaminya kelak. Setelah menikah, seorang perempuan akan tinggal dan menjadi bagian yang menyatu dengan keluarga suami. Perempuan Sumba dihargai juga dikagumi karena kekuatan karakter femininnya, melebihi dari pada tampilannya secara fisik. Dalam hal ini dapat dikatakan bahwa nilai kecantikan seorang perempuan Sumba dimaknai dari karakter dan kepribadiannya. Nilai kecantikan karakter perempuan Sumba terus diwariskan dari generasi ke generasi. Perempuan harus rajin, dapat bekerja di dapur, sopan, bertutur kata yang baik, serta mampu menjaga nama baik keluarga besarnya (klan). Budaya masyarakat Sumba sangat kolektivis, perempuan wajib untuk memenuhi nilai dan standar hidup masyarakat termasuk standar perilaku dan karakter feminin sebagai seorang perempuan.

Perkembangan media dan teknologi membawa dampak tersendiri baik positif maupun negatif. Dalam perkembangannya dampak positif media dapat menjadikan komunitas lebih berdaya (Setiyaningsih \& Fahmi, 2020; Triono \& Setiyaningsih, 2017). Telah menjadi bagian dari keseharian remaja di Kota Waingapu, maka makna kecantikan perempuan Sumba secara budaya. Makna kecantikan yang banyak disajikan di media massa termasuk juga media sosial, terus hadir dan menjadi satu dalam kehidupan dan interaksi sosial. Tidak dapat dipungkiri bahwa media memainkan peran yang signifikan dalam memberikan gambaran mengenai sebuah realitas, sebagaimana yang dikatakan Walter Lippman mengenai pseudoenvironment atau the picture in our head (Lippman, 1922). Media memberikan cara pandang mengenai bagaimana manusia harus melihat dan memahami sebuah realitas, termasuk realitas mengenai kecantikan perempuan.

Salah satu hal yang sering ditayangkan di media adalah gambaran mengenai kecantikan. Media membangun konstruksi mengenai bagaimana seharusnya masyarakat menilai mengenai kecantikan. Artis atau selebriti dengan ciri tertentu dipilih untuk melakukan promosi berbagai produk kecantikan melalui iklan di berbagai media, sehingga mampu membentuk standar tertentu dalam menilai dan memahami mengenai kecantikan. Media mampu membangun konsensus sosial untuk menilai tubuh perempuan melalui proses komersial (Xu, 2019). Dalam beberapa penelitian, nilai mengenai kecantikan yang ada di media digambarkan dengan ciri fisik seperti tinggi, putih, langsing (Puspitasari, 2020; Bertilsson \& Gillberg, 2017b). Nilai yang hadir di media ini dapat melebur dalam proses interaksi yang melahirkan pemaknaan mengenai kecantikan itu sendiri.

Berdasarkan hasil wawancara, peneliti menemukan bahwa remaja di kota 
Waingapu berusaha memaknai kecantikan secara ideal yakni kecantikan sebagai perwujudan dari karakter yang baik, rajin, dan suka menolong. Hal ini serupa dengan nilai yang diwariskan dalam konteks masyarakat dan budaya di Sumba, dimana perempuan lebih dituntut untuk menumbuhkan dan merawat karakter dibandingkan dengan merawat kecantikan fisik. Pertanyaan berupa "Bagaimana kamu memahami tentang kecantikan?" atau "Apa arti cantik menurutmu?" direspon remaja dengan menjelaskan bahwa cantik bukan tentang fisik melainkan mengenai karakter. Hal ini dapat terlihat dari respon yang diberikan oleh satu informan sebagai berikut "kalau menurt saya sih kak, kalau seseorang tuh dinilai cantik tuh bukan cantik dari muka, tapi muka itu ya urusan nanti, tapi yang paling pertama tu sifat". Informan lainnya juga mengatakan bahwa "kecantikan bukan hanya berasal dari wajah, atau bukan dari putih atau tidaknya seseorang, mukanya bagus atau tidak, tetapi sikap". Upaya untuk memprioritaskan kecantikan karakter dibandingkan kecantikan fisik tetap menyisakan ruang bahwa terdapat makna kecantikan lain yang mereka pahami, tetapi mereka memilih untuk bersandar pada pemahaman cantik secara karakter sebagai yang terpenting.

Pemaknaan cantik sebagai perwujudan karakter yang baik tidak terlalu mengakar dalam cara berpikir remaja. Remaja memiliki pemaknaan bahwa cantik juga relevan dengan konstruksi yang banyak digambarkan di media. Walaupun remaja merespon bahwa kecantikan tidak saja harus dilihat dari ciri fisik melainkan juga karakter, tetapi ketika mereka harus menjawab pertanyaan mengenai "mengapa kamu menilai teman atau mungkin artis tertentu sebagai pribadi yang cantik?", maka mereka cenderung mendeskripsikannya dari ciri-ciri fisiknya. Teman atau selebriti yang cantik dimaknai berdasarkan ciri wajah yang mulus bebas jerawat, memiliki postur tubuh yang tinggi dan ideal, putih dan rambut yang lurus. Remaja juga merespon bahwa apabila kriteria cantik tersebut tidak ada pada diri mereka, maka mereka menilai bahwa hal tersebut sebagai kekurangan yang ada pada fisik mereka. Nilai kecantikan tersebut sesuai dengan yang sering dikonstruksikan oleh media.

Sumba merupakan sebuah pulau beriklim tropis yang berbatasan dengan Samudera Indonesia di sebelah Barat dan Selatan. Saat ini Sumba memiliki 4 kabupaten, yakni Sumba Timur, Sumba Tengah, Sumba Barat, dan Sumba Barat Daya. Iklim di Sumba Timur dengan Ibu Kota Waingapu cenderung lebih kering dibandingkan dengan tiga kabupaten lainnya. Suhu udara di Kota Waingapu pada Januari 2020 misalnya mencapai suhu udara rata-rata adalah 29 derajat Celsius dan suhu maksimum dapat mencapai 36 derajat Celsius (BMKG, 2020). Sebagai masyarakat yang secara geografis bermukim di daerah beriklim tropis dan kering, maka ciri fisik penduduk Sumba yang umum ditemui akan sangat berbeda dengan 
gambaran fisik yang sering terdapat pada media. Masyarakat Waingapu umumnya berkulit sawo matang, dengan tipikal rambut yang lebih bergelombang. Untuk tinggi badan, umumnya orang Sumba bertubuh tinggi baik laki-laki maupun perempuan. Berdasarkan ciri fisik tersebut, maka ciri berupa kulit putih dan rambut yang lurus memang jarang tampak dalam realitas budaya masyarakat Waingapu. Pemahaman remaja Waingapu akan ciri cantik fisik berupa kulit putih, dan rambut yang lurus ditemukan melalui konstruksi yang ada di berbagai media sebagaimana yang telah disebutkan pada penelitian-penelitian terdahulu.

Selain menilai kecantikan orang lain berdasarkan ciri fisiknya, remaja yang menjadi informan dalam penelitian ini juga berupaya untuk mencapai ekspektasi nilai kecantikan sebagaimana yang digambarkan oleh media. Nilai kecantikan media yang melekat pada pemikiran remaja dan berusaha untuk dicapai adalah memiliki wajah yang mulus dan bebas jerawat. Penelitian ini juga menemukan bahwa remaja selalu mengasosiasikan cantik dengan wajah mulus yang bebas jerawat. Pemaknaan ini berkaitan erat dengan konteks biologis, psikologis dan sosial dari remaja. Kilkeny dalam (Narayenah \& Suryawati, 2017) menjelaskan bahwa masa remaja merupakan masa dimana terjadinya perubahan fisik yang dapat menjadi pemicu jerawat, oleh karena itu persoalan mengenai jerawat merupakan hal yang sulit untuk dihindari. Disisi lain masa remaja juga masa dimana seorang individu mengutamakan presentasi diri (Livingstone, 2008). Remaja ingin selalu tampil cantik, dan dalam lingkungan sosial remaja banyak berinteraksi dengan media termasuk juga media sosial yang menawarkan berbagai gambaran mengenai kecantikan.

Remaja di Sumba khususnya di Waingapu hidup dalam dua ekspektasi nilai ataupun cara pandang mengenai kecantikan seorang perempuan, yakni nilai dalam tuntutan budaya dan nilai dalam tuntutan media. Kondisi ini memunculkan disonansi bagi remaja dalam menginternalisasikan makna kecantikan, khususnya pada halhal yang tidak mampu dipenuhi, seperti keterbatasan secara fisik atau genetik. Istilah disonansi dalam konteks ini merujuk pada kondisi pertukaran makna dalam interaksi sosial, dimana hadirnya dua nilai kecantikan yang membingungkan bagi remaja terkait nilai mana yang sesungguhnya paling penting untuk mereka pegang. Di satu sisi remaja memaknai secara karakter sebagaimana yang umum dalam konteks budaya masyarakat Sumba, tetapi disisi lain mereka juga merasa kurang cantik dibandingkan dengan remaja yang lain berdasarkan ciri fisik. Menariknya ciri kecantikan fisik remaja di Sumba serupa dengan gambaran cantik yang ada di media. Remaja berpandangan bahwa cantik secara fisik memiliki ciri tinggi, wajah mulus, berambut lurus, dan putih. Hanya satu informan yang memang tampak bingung dan kesulitan dalam memberikan jawaban mengenai bagaimana cantik secara fisik dalam pandangannya, dan cenderung tidak pernah memperhatikan orang lain dalam definisi cantik secara fisik. 
Tabel 1. Klasifikasi Hasil Wawancara

\begin{tabular}{|l|l|}
\hline Klasifikasi Pertanyaan Wawancara & \multicolumn{1}{|c|}{ Respon Informan } \\
\hline Makna cantik & $\begin{array}{l}\text { Karakter: good attitude, suka } \\
\text { menolong, cerdas, jujur }\end{array}$ \\
\hline Penilaian cantik terhadap orang lain & $\begin{array}{l}\text { Dilihat dari kriteria fisik: wajah bersih } \\
\text { bebas jerawat, tinggi, badan ideal, } \\
\text { putih, rambut lurus }\end{array}$ \\
\hline Penilaian cantik terhadap diri sendiri & $\begin{array}{l}\text { Tidak 100\% merasa cantik, karena } \\
\text { masih ada kekurangan yang terlihat } \\
\text { secara fisik, yaitu wajah berjerawat, } \\
\text { tidak putih, badan kurang ideal }\end{array}$ \\
\hline Cara mempercantik diri & $\begin{array}{l}\text { Menggunakan perawatan berupa } \\
\text { skincare }\end{array}$ \\
\hline
\end{tabular}

Sumber: Data Penelitian, 2020

Dalam teori Social Comparison, Festinger (1954) mengatakan bahwa manusia melakukan evaluasi pandangan atau kemampuannya melalui perbandingan dengan orang lain. Remaja membandingkan tampilan fisik mereka dengan apa yang mereka banyak temui dari media dan iklan produk kecantikan. Untuk ciri fisik yang ada pada gambaran di media, namun tidak ada pada diri remaja, mereka mengakui hal tersebut sebagai sebuah kekurangan yang membuat kurang percaya diri atau membuat mereka merasa kurang cantik, seperti halnya masalah wajah berjerawat, tidak putih, dan tidak memiliki badan yang ideal. Di sisi lain, apabila gambaran di media sudah sesuai dengan ciri yang ada pada fisik mereka, maka remaja merasa bahwa mereka puas dengan kondisi tersebut, sebagaimana misalnya mengenai tinggi badan. Remaja di Waingapu rata-rata memiliki bentuk tubuh yang tinggi, sehingga masalah tinggi badan sebagaimana yang banyak dihadirkan di media, tidak menjadi masalah yang membuat mereka tidak cantik secara fisik

Remaja di Kota Waingapu mengalami disonansi dalam pemaknaan mengenai kecantikan. Remaja sulit untuk melepaskan makna cantik secara fisik sebagaimana gambaran yang ada di media, khususnya apabila ciri tersebut tidak mereka miliki seperti warna kulit, bentuk rambut, dan kondisi wajah (berjerawat atau tidak). Remaja mengalami disonansi, dimana secara budaya masyarakat Sumba termasuk juga di Kota Waingapu banyak dibentuk dengan nilai dimana perempuan yang cantik lebih diagungkan dengan melihat karakter, tetapi disisi lain dalam realitas sebagai remaja mereka juga mellihat konstruski cantik yang banyak disajikan di media. Remaja di Kota Waingapu menyadari bahwa makna cantik tidak selalu mengenai tampilan fisik, tetapi disisi lain mereka juga tetap berusaha untuk 
mencapai kecantikan secara fisik dengan menggunakan produk kecantikan, sebagaimana yang sering digambarkan oleh media.

\section{4 | SIMPULAN}

Remaja di kota Waingapu mengalami disonansi makna mengenai kecantikan. Disonansi terjadi pada saat remaja memaknai kecantikan dalam dua sisi yang bertolak belakang yakni kecantikan secara fisik sebagaimana yang ada pada konstruksi media dan kecantikan secara budaya. Remaja di Waingapu menyadari bahwa kecantikan yang terpenting adalah dari karakter baik yang dimiliki seseorang sebagaimana nilai yang sering diajarkan dalam keluarga dan masyarakat. Tetapi pandangan ini akan berubah ketika remaja mulai menilai kecantikan orang lain dan mengevaluasi kecantikan diri sendiri. Makna kecantikan yang digambarkan pada penelitian ini belum mampu menjelaskan makna kecantikan remaja di Sumba dalam berbagai setting atau konteks seperti pada daerah atau kawasan yang masih jauh dari perkembangan teknologi informasi dan komunikasi. Penelitian dalam konteks yang berbeda penting dikaji untuk memberikan perspektif yang menyeluruh mengenai proses interaksi dan produksi makna kecantikan di Pulau Sumba. Pemahaman akan produksi makna di masyarakat dapat memberikan ruang bagi peneliti, pemerhati budaya, maupun bagi pemerintah untuk dapat membangun ataupun memelihara sebuah konstruksi makna yang sesuai dengan khasanah budaya masyarakat di Sumba.

\section{REFERENSI}

Adjin-Tettey, T. D. (2015). A Study Exploring the Influence of Media Consumption on Body Image and Beauty Among Young Corporate Ghanaian Women in the Greater Accra Region. Journal of Business Research, 9, 28-43.

Aksan, N., Kısac, B., Aydın, M., \& Demirbuken, S. (2009). Symbolic interaction theory. Elsevier, 902-904.

Andrea, B., Gabriella, H.-C., \& Tímea, J. (2016). Y and Z Generations at

Workplaces. Journal of Competitiveness, 8(3), 90-106.

Bandura, A. (1971). Social Learning Theory. General Learning Press.

Ben-Nun, L. (2016). BEAUTY OF HUMANS. B.N. Publication House.

Bertilsson, E., \& Gillberg, E. (2017). The Communicated Beauty Ideal on Social Media. JÖNKÖPING University.

Blumer, H. (1969). Symbolic Interactionism: Perspective and Method. Prentice-Hall, Inc.

BMKG. (2020). Buletin Meteorologi Stasiun Meteorologi Umbu Mehang Kunda Edisi Februari 2020. 
Callero, P. L. (2003). The Sociology of the Self. Annual Review of Sociology, 29, 115-133.

Carter, M. J., \& Fuller, C. (2015). Symbolic Interactionism. Sociopedia.Isa. https://doi.org/DOI: 10.1177/205684601561

Corcoran, K., Crusius, J., \& Mussweiler, T. (2011). Social Comparison: Motives, Standards, and Mechanisms. In D. Chadee (Ed.), Theories in Social Psychology (pp. 119-139). Blackwell Publishing, Ltd.

Dennis, A. (2011). Symbolic Interactionism and Ethnomethodology. Symbolic Interaction, 34(3), 349-356.

Dolot, A. (2018). The characteristics of Generation Z. E-Mentor, 44-50.

El-Kilany, E., \& Raoof, E. (2017). Facial Cosmetics in Ancient Egypt. Egyptian Journals of El-Kilany, Engy, Dan Enas Raoof. 2017. "Facial Cosmetics in Ancient Egypt." Egyptian Journals of Tourism Studies VI(1).

Https://Www.Academia.Edu/33510332/Facial_Cosmetics_in_Ancient_Egypt_By. Tourism Studies, VI(1).

Festinger, L. (1954). A Theory of Social Comparison Process. Sage. https://doi.org/https://doi.org/10.1177/001872675400700202

Fridha, M., \& Octavianti, M. (2016). Konstruksi Makna Kencan di Situs Pencarian Jodoh Tinder (Studi Fenomenologi Pada Pria Pengguna Tinder Di Jakarta). Nomosleca, 2(2).

Gaidhani, S., Aurora, L., \& Sharma, B. K. (2019). UNDERSTANDING THE ATTITUDE OF GENERATION Z TOWARDS WORKPLACE. Intenational Journal of Management, Technology, and Engineering, IX(1), 2804.

Griffin, E., Ledbetter, A., \& Sparks, G. (2015). A First Look at Communication

Theory. McGraw-Hill Education.

Ibanga, D.-A. (2017). The Concept of Beauty in African Philosophy.

Kasturi, S. K., \& Vardhan, P. B. (2014). SOCIAL MEDIA: KEY ISSUES AND NEW CHALLENGES - A STUDY OF NALGONDA DISTRICT. Global Media JournalIndian Edition, 5(1).

Laarhoven, S., \& Wang, D. J. (2018). Social media, beauty standards and Chinese women.

Lippman, W. (1922). Public Opinion. Macmillan.

Littlejohn, S. W., \& Foss, K. A. (2009). Teori Komunikasi (9th ed.). Salemba Humanika.

Livingstone, S. (2008). Taking risky opportunities in youthful content creation: teenagers' use of social networking sites for intimacy, privacy and selfexpression. New Media \& Society, 10(3), 393-411.

https://doi.org/10.1177/1461444808089415 
Mead, G. H. (1934). Mind, Self, and Society: From the Standpoint of A Social Behaviorist (C. W. Morris (ed.)). The University of Chicago Press.

Miller, M. K., Reichert, J., \& Flores, D. (2015). Social Comparison Theory. In G.

Ritzer (Ed.), The Blackwell Encyclopedia of Sociology. John Wiley \& Sons, Ltd.

Mills, J. S., Shannon, A., \& Hogue, J. (2017). Beauty, Body Image, and the Media.

In Perception of Beauty. https://doi.org/10.5772/intechopen.68944

Nabavi, R. T. (2012). Bandura's Social Learning Theory \& Social Cognitive Learning Theory.

Nagar, I., \& Virk, R. (2017). The Struggle Between the Real and Ideal: Impact of Acute Media Exposure on Body Image of Young Indian Women. Sage Open, $7(1)$.

Narayenah, M., \& Suryawati, N. (2017). Karakteristik profil jerawat berdasarkan indeks glikemik makanan pada mahasiswa semester III fakultas kedokteran Universitas Udayana tahun 2014. Intisari Sains Medis, 8(2), 139-143.

Neuman, W. L. (2014). Social Research Methods: Qualitative and Quantitative Approaches (Seventh). Pearson Education Limited.

Obar, J. A., \& Wildman, S. S. (2015). Social Media Definition and the Governance

Challenge: An Introduction to the Special Issue.

Paus-Hasebrink, I., Kulterer, J., \& Sinner, S. (2019). The Role of Media Within

Young People's Socialisation: A Theoretical Approach: A Longitudinal Study of the Mediatization of Socialisation. https://doi.org/10.1007/978-3-030-02653-0_3 Prijanti, D. (2013). Indonesian female beauty concept: Does it take into account the traditional values? The Asian Conference on Media and Mass Communication.

Puspitasari, D. (2020). Discourse on the shifting of local beauty: Concepts in an

Easternization era. Yudi Suryadi, 33(1), 36-46.

Septiyani, I. (2013). WOMEN AUDIENCE INTERPRETATION TOWARDS BEAUTY CONSTRUCTION IN INSTGARAM ACCOUNT OF UNDIP CANTIK.

Diponegoro.

Setiyaningsih, L. A., \& Fahmi, M. H. (2020). Penguatan Community Development

Petani Nanas Desa Palaan melalui Digital Marketing. Abdimas: Jurnal

Pengabdian Masyarakat Universitas Merdeka Malang, 5(2), 145-151.

https://doi.org/10.26905/abdimas.v5i2.4361

Smith, W. J. (1980). The Behaviour of Communicating: An Ethological Approach.

Harvard University Press.

Snow, D. A. (2001). Extending and Broadening Blumer's Conceptualization of

Symbolic Interactionism. Symbolic Interactionism, 24(3), 367377.

Soman, U. (2009). Patriarchy: Theoretical Postulates and Empirical Findings.

Sociological Bulletin, 253-272.

Strahan, E. J., Wilson, A. E., Cressman, K. E., \& Buote, V. M. (2006). Comparing to perfection: How cultural norms for appearance affect social comparisons and 
self-image. Body Image, 3(3), 211-227.

Triono, M. A., \& Setiyaningsih, L. A. (2017). Desain Disonansi Kognitif Sebagai

Faktor Anteseden Untuk Penguatan Kualitas Informasi Pada Website. Seminar

Nasional Sistem Informasi, 1(1), 71-79. http://eprints.unmer.ac.id

Webb, H. J., Zimmer-Gembeck, M. J., Waters, A. M., Farrell, L. J., Nesdale, D., \&

Downey, G. (2017). Pretty Pressure" From Peers, Parents, and the Media: A

Longitudinal Study of Appearance-Based Rejection Sensitivity. Journal of

Research on Adolescence, 27(4), 718-735.

Weisner, S., \& Silver, M. (1981). Community work and social-learning theory. Social Work, 26(2), 146-150.

Xu, X. (2019). Is "Beautiful Female Something" Symbolic Capital or Symbolic Violence? That Is a Question. Sage Open, 9(2). 